\title{
Perbedaan Kemampuan Berpikir Kreatif Dan Berpikir Kritis Siswa yang Diajar Menggunakan Pembelajaran Konvensional Dengan Kontekstual
}

\author{
Ronald Mahmud Sitorus ${ }^{1}$, Ilham Nazaruddin ${ }^{2}$ \\ ${ }^{1}$ Prodi Pendidikan Matematika, STKIP Amal Bakti, Medan, Indonesia \\ ${ }^{2}$ Pendidikan PGSD, STKIP Amal Bakti, Medan, Indonesia \\ Email: ronaldregen710@gmail.com
}

\begin{abstract}
ABSTRAK
Tujuan dari penelitian ini untuk mengetahui (1) Untuk mengetahui bahwa terdapat perbedaan yang signifikan antara kemampuan berpikir kreatif siswa yang memperoleh pembelajaran kontekstual dengan siswa yang memperoleh pembelajaran konvensional, (2) Untuk mengetahui bahwa terdapat perbedaan yang signifikan antara kemampuan berpikir kritis siswa yang memperoleh pembelajaran kontekstual dengan siswa yang memperoleh pembelajaran konvensional, (3) Untuk mengetahui aktivitas siswa selama proses pembelajaran yang diajarkan dengan pembelajaran kontekstual dan yang diajarkan dengan pembelajaran Konvensional, (4) Untuk mengetahui respon siswa terhadap kegiatan yang diajarkan dengan pembelajaran kontekstual dan yang diajarkan dengan pembelajaran konvensional. Populasi penelitian ini adalah siswa kelas X SMA Negeri 2 Binjai. Kemudian secara acak dipilih tiga kelas dari semua kelas X SMA Negeri 2 binjai yaitu kelas XA, kelas XB, dan kelas XC dimana kelas XA sebagai kelas eksperimen dan kelas XB sebagai kelas kontrol serta kelas XC sebagai kelas uji coba instrumen. Kelas uji coba digunakan untuk menyempurnakan perangkat pembelajaran yang dikembangkan dengan menerapkan pembelajaran kontekstual. Instrumen penelitian ini menggunakan tes berpikir kreatif dan berpikir kritis matematis. Instrumen tersebut telah di uji oleh validator dan telah memenuhi syarat validitas isi, serta koefisien reabilitas. Hasil penelitian menunjukkan bahwa (1) Dari hasil perhitungan uji $F$, dihasilkan bahwa $F_{\text {hitung }}=102,477$ dan $F_{\text {tabel }}=4,006873$ dengan taraf signifikan sebesar 5\% Jika $F_{\text {hitung }} \geq F_{\text {tabel }}$ maka $H_{0}$ ditolak dan $H_{a}$ diterima artinya terdapat perbedaan yang signifikan antara kemampuan berpikir kreatif siswa yang memperoleh pembelajaran kontekstual dengan siswa yang memperoleh pembelajaran konvensional (2) Dari hasil perhitungan uji $F$, dihasilkan bahwa $F_{\text {hitung }}=7,557737$ dan $F_{\text {tabel }}=4,006873$ dengan taraf signifikan sebesar 5\% Jika $F_{\text {hitung }} \geq F_{\text {tabel }}$ maka $H_{0}$ ditolak dan $H_{a}$ diterima artinya terdapat perbedaan yang signifikan antara kemampuan berpikir kritis siswa yang memperoleh pembelajaran kontekstual dengan siswa yang memperoleh pembelajaran konvensional, (3) Keaktifan siswa dalam pembelajaran kontekstual dan konvensional memenuhi batas toleransi, (4) Rata - rata persentase keseluruhan komponen respon siswa terhadap pembelajaran kontekstual dan konvensional lebih besar atau sama dengan 80\%, maka disimpulkan bahwa respon siswa terhadap pembelajaran kontekstual dan konvensional adalah positif (5) Proses penyelesaian jawaban siswa dengan menggunakan pembelajaran kontekstual memiliki kriteria baik. Hal ini ditunjukkan dengan jawaban siswa dalam menyelesaikan tes kemampuan berpikir kreatif dan berpikir kritis siswa lebih baik pada kelas pembelajaran kontekstual dibandingkan dengan pembelajaran konvensional.
\end{abstract}

Kata kunci: Pembelajaran Kontekstual, kemampuan berpikir kreatif, dan kemampuan berpikir kritis siswa 


\begin{abstract}
This study aimed to determine (1) To know that there are significant differences between creative thinking abilities of students who obtain contextual learning and students who received conventional learning, (2) To know that there are significant differences between critical thinking skills students acquire learning Contextual and the students who received conventional learning, (3) To determine the activity of students during the learning process taught by contextual learning and being taught by Conventional method, (4) To determine the students' response to the activities taught by contextual learning and being taught by conventional teaching, The study population was class X SMA Negeri 2 Binjai. Then randomly selected from all three classes of class X SMA Negeri 2 Binjai is class XA, $X B$, and the class of $X A$ and $X C$ as an experimental class, and control class as a class of XB and XC as the class of test instruments. Class tests are used to enhance learning device that was developed by applying contextual learning. The research instrument used tests of creative thinking and critical thinking mathematically. The instrument has been tested by the validator and has qualified content validity and reliability coefficients. The results showed that (1) From the results of the F test calculation, resulting that $=102.477$ and $=4.006873$ with significance level of $5 \%$ If $F_{\text {hitung }} \geq F_{\text {tabel }}$ then $H_{0}$ rejected and $H_{a}$ accepted means there is a significant difference between the creative thinking abilities of students who obtain contextual learning with students who received conventional learning (2) The calculation of $F$ test, and the result that $F_{\text {hitung }}=7,557737$ and $F_{\text {tabel }}=4,006873$ with significance level of $5 \%$ If $F_{\text {hitung }} \geq F_{\text {tabel }}$ then $H_{0}$ rejected and $H_{a}$ accepted means that there are significant differences between students' critical thinking skills who obtain contextual learning with students who received conventional learning, (3) ) The active participation by students in contextual learning and conventional meets the tolerance limits, (4) Averages percentage of total components of students' responses to contextual learning and conventional greater than or equal to $80 \%$, then concluded that students' response to conventional and contextual learning is positive (5) The process of settlement of the students' answers using contextual learning has both criteria. This is shown by the students' answers in completing the test the ability of creative thinking and critical thinking of students are better on the class contextual learning compared to conventional learning.
\end{abstract}

Keywords: Contextual learning, Students' creative thinking skills and critical thinking skills

\section{A. Pendahuluan}

Salah satu diantara masalah besar yang dihadapi dunia pendidikan di Indonesia akhirakhir ini yang banyak diperbincangkan dari berbagai kalangan adalah rendahnya kualitas pendidikan. Pembelajaran adalah inti dari aktivitas pendidikan, oleh sebab itu pemecahan masalah rendahnya kualitas pendidikan harus difokuskan pada kualitas pembelajaran. Komponenkomponen yang dapat berpengaruh terhadap kegiatan proses pembelajaran adalah guru, siswa, alat dan media dan faktor lingkungan (Sanjaya, 2006:52). Kualitas pembelajaran dapat diwujudkan bilamana proses pembelajaran direncanakan dan dirancang secara matang dan seksama tahap demi tahap dan proses demi proses (Edgar, 2005:168).

Menurut Survei Human Developement Indeks, kualitas sumber daya manusia saat ini menduduki peringkat ke-105. Peringkat ini gambaran nyata masih rendahnya mutu pendidikan di Indonesia. Ada tiga variabel yang sangat menentukan kualitas pendidikan yaitu guru yang kualitasnya tinggi, proses belajar mengajar yang tepat dan buku pelajaran.

Proses belajar mengajar yang baik harus sesuai dengan prinsip pembelajaran. Prinsip pembelajaran menurut Larsen dan Freeman (1986 dalam Supani dkk. 1997/1998) adalah represent the theoretical framework of the method. Prinsip pembelajaran adalah kerangka teoritis sebuah metode pembelajaran. Kerangka teoretis adalah teori-teori yang mengarahkan harus bagaimana sebuah metode dilihat dari segi:

1. Bahan yang akan dibelajarkan,

2. Prosedur pembelajaran (bagaimana siswa belajar dan bagaimana guru mengajarkan bahan),

3. Gurunya, dan

4. Siswanya.

Dengan model tersebut guru dapat membantu siswa mendapatkan atau memperoleh informasi, ide, keterampilan, cara berpikir, dan 
mengekspresikan ide diri sendiri. Selain itu, model belajar juga mengajarkan bagaimana mereka belajar.

Suatu model pembelajaran akan memuat antara lain: (a) Deskripsi lingkungan belajar, (b) Pendekatan, metode, teknik, dan strategi, (c) Manfaat pembelajaran, (d) Materi pembelajaran (kurikulum), (e) Media, dan (f) desain pembelajaran. Ada banyak model pembelajaran yang dapat digunakan dalam implementasi pembelajaran di antaranya sebagai berikut (lihat Octavia Shilphy A, 2020): (a) Model pembelajaran kontekstual (CTL), (b) Model pembelajaran berdasarkan masalah, (c) Model pembelajaran konstruktivisme, (d) Model dengan pendekatan lingkungan, (e) Model pengajaran langsung, (f) Model pembelajarn terpadu, dan (d) Model pembelajaran interaktif. (Octavia Shilphy A, 2020).

Pembelajaran kontekstual adalah pembelajaran yang menekankan kepada proses keterlibatan siswa secara penuh untuk dapat menemukan materi yang dipelajari dan menghubungkan dengn situasi kehidupan nyata sehingga mendorong siswa secara penuh untuk dapat menemukan materi yang dipelajari dan menghubungkannya dengan situasi kehidupan nyata sehingga mendorong siswa untuk dapat menerapkannya dalam kehidupan mereka (Anam, 2021:24).

Metode pembelajaran kontekstual yang semacam ini lebih menekankan kepada para peserta didik untuk melihat, merasakan, mendengar dan mengalami apa yang disampaikan oleh tenaga pendidiknya di dunia nyata.Orientasi kurikulum 2013 adalah terjadinya peningkatan dan keseimbangan antara kompetensi sikap, keterampilan dan pengetahuan. Hal itu sejalan dengan amanat UU No.20 tahun 2003 sebagaimana tersurat dalam penjelasan pasal 35: "kompetensi lulusan merupakan kualifikasi kemampuan lulusan yang mencakup sikap, pengetahuan, dan keterampilan sesuai dengan standar yang telah disepakati”. Hal ini sejalan pula dengan pengembangan kurikulum berbasis kompetensi yang telah dirintis pada tahun 2004 dengan mencangkup kompetensi sikap, pengetahuan, dan keterampilan secara terpadu. Secara konseptual kurikulum 2013 jelas ada perubahan signifikan. Perubahan itu tentunya di maksudkan untuk menjadikan pendidikan menjadi lebih baik. Salah satu alasan Pemerintah merubah Kurikulum 2006 menjadi Kurikulum 2013, diindikasikan dari yang dikemukakan oleh
Menteri Pendidikan dan Kebudayaan adalah lemahnya "kreativitas siswa". Salah satu cara mengatasinya adalah dengan mengajak siswa belajar mengamati. Memanfaatkan indrawi untuk melihat fenomena. Tidak hanya mengamati, tetapi didorong untuk bertanya, menalar, dan mencoba.

Berdasarkan fungsi dan tujuan Pendidikan Nasional tersebut kita ketahui bahwa salah satu hasil (output) yang diharapkan dari sebuah proses pendidikan ialah agar para peserta didik menjadi manusia kreatif. Karena tidak dapat dipungkiri, untuk mengantisipasi perkembangan ilmu pengetahuan dan teknologi yang semakin maju, maka perkembangannya menuntut lahirnya manusia-manusia yang kreatif, profesional, dan mempunyai kepedulian terhadap masalahmasalah yang timbul dalam masyarakat. Oleh karena itu, pendidikan yang diselenggarakan harus menggarahkan anak didik untuk dapat menjadi kreatif.

Kreativitas memang penting, namun bangsa Indonesia ternyata masih menghadapi persoalan dalam masalah ini. Khususnya dalam pendidikan, pakar-pakar dalam bidang pendidikan melihat bahwa kreativitas bangsa Indonesia masih tergolong rendah. Hal tersebut ternyata juga berlaku dalam bidang matematika dan sains, sebagaimana hasil penelitian internasional dalam bidang matematika dan IPA (TIMSS) untuk kelas dua SLTP (eighth grade), menunjukan bukti bahwa soal - soal matematika tidak rutin yang memerlukan kemampuan berpikir tingkat tinggi pada umumnya tidak berhasil dijawab dengan benar oleh sampel siswa Indonesia". Hal ini berarti kemampuan berpikir tingkat tinggi siswa yang di antaranya kemampuan berpikir kritis dan kreatif dalam matematika perlu menjadi perhatian utama.

Hasil wawancara dengan guru di SMA Negeri 2 Binjai pada tanggal 23 Maret 2019, diperoleh keterangan bahwa guru masih mengajarkan materi kepada siswa dengan metode pembelajaran konvensional dan memberikan soalsoal rutin. Hal ini menyebabkan kemampuan berpikir kreatif dan kritis siswa kurang tergali akibatnya akan berdampak pada penguasaan konsep matematika di jenjang pendidikan siswa berikutnya. Selain itu diperoleh juga keterangan bahwa di sekolah tersebut belum pernah dilaksanakan evaluasi pembelajaran khususnya untuk mengukur kemampuan berpikir matematis peserta didik.

Dari hasil observasi uji awal di SMA Negeri

2 Binjai pada tanggal 24 Maret 2019, peneliti 
mendapatkan siswa kesulitan dalam menyelesaikan soal yang berhubungan dengan ruang lingkup kehidupan sehari-hari yang dapat mengembangkan Kemampuan Berpikir Kreatif siswa pada saat menyelesaikannya. Salah satu materi yang dianggap sulit oleh siswa yaitu tentang Geometri Bidang Datar. Kenyataan yang terjadi di lapangan sebagian siswa tidak memahami maksud soal yaitu tidak mengetahui apa yang diketahui dan apa yang ditanya pada soal. Untuk memperoleh gambaran lebih jelas, berikut ini akan disajikan salah satu contoh soal uji awal di SMA Negeri 2 Binjai. Ada sebuah kawat yang berbentuk garis seperti gambar di bawah ini, dengan ukuran $B N=8 \mathrm{~cm}$. jika panjang $B N=$ $\frac{1}{4} A B$. Berapakah ukuran panjang kawat tersebut?

Dari penelitian uji awal yang dilakukan peneliti dilapangan pada tanggal 24 Maret 2019 pada tes kemampuan berpikir kreatif dapat dilihat perbandingan antara hasil alternatif jawaban yang benar dengan jawaban yang dibuat siswa. Berikut ini adalah alternatif jawaban yang benar pada contoh soal kemampuan berpikir kreatif di atas adalah sebagai berikut:

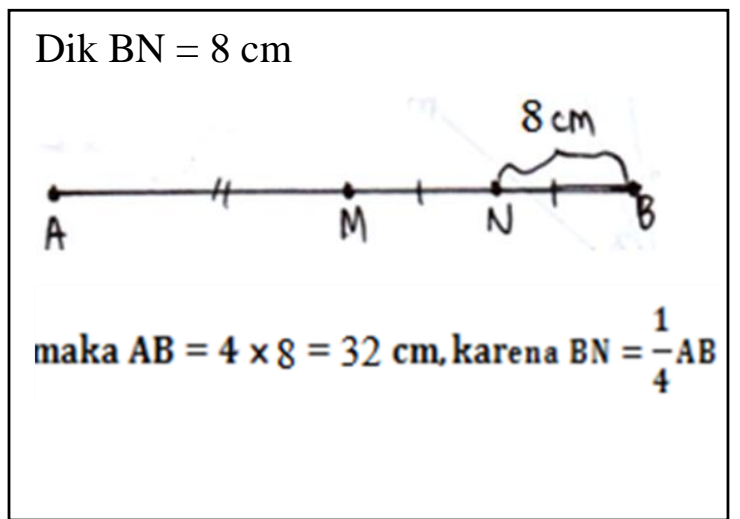

\section{Gambar 1. Alternatif Jawaban yang benar pada contoh soal kemampuan berpikir kreatif}

Dan berikut ini salah satu contoh jawaban siswa dari persoalan di atas,

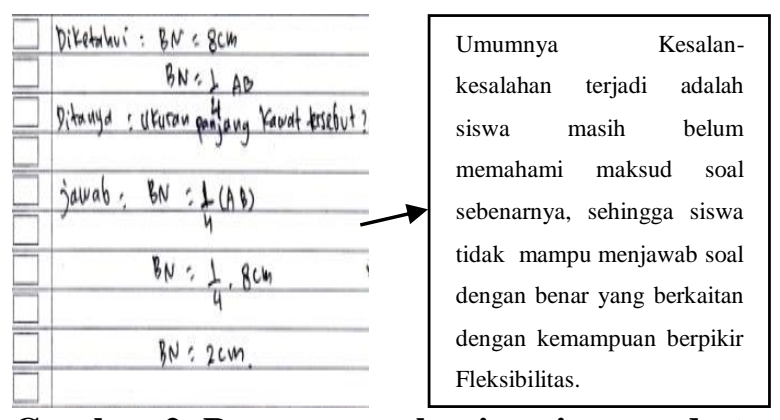

Gambar 2. Proses penyelesaian siswa pada tes uji awal

Dari jawaban siswa di atas, terlihat bahwa kemampuan berpikir kreatif siswa masih rendah. Hal ini terlihat siswa mencoba menyelesaian soal tersebut, banyak siswa yang mengalami kesulitan untuk menentukan ukuran panjang kawat tersebut. Dari 30 siswa yang menjawab soal tersebut hanya 2 siswa yang menjawab soal tersebut $(6,7 \%)$ yang menjawab benar, 19 siswa $(63,3 \%)$ menjawab salah dan 9 siswa (30\%) tidak mampu menjawab sama sekali. Hal ini menunjukkan bahwa kemampuan berpikir kreatif siswa masih rendah.

Selain kemampuan berpikir kreatif, tak kalah pentingnya adalah kemampuan berpikir kritis siswa. Kemampuan berpikir kritis siswa dalam dalam pembelajaran matematika sangat penting untuk diperhatikan, hal ini dikarenakan melalui kemampuan berpikir kritis matematika siswa bisa menyusun rencana penyelesaian masalah yang paling tepat untuk digunakan misalnya mengungkap teorema/konsep/definisi yang akan digunakan, menggali akibat dari suatu pernyataan, menggali kemungkinan adanya bias dan sebagainya.

Dari hasil observasi uji awal di SMA Negeri 2 Binjai pada tanggal 24 Maret 2019, peneliti mendapatkan siswa kesulitan dalam menyelesaikan soal yang berhubungan dengan ruang lingkup kehidupan sehari-hari yang dapat mengembangkan Kemampuan Berpikir Kritis siswa pada saat menyelesaikannya. Salah satu materi yang dianggap sulit oleh siswa yaitu tentang Geometri Bidang Datar. Kenyataan yang terjadi di lapangan sebagian siswa tidak memahami maksud soal yaitu tidak mengetahui apa yang diketahui dan apa yang ditanya pada soal. Untuk memperoleh gambaran lebih jelas, berikut ini akan disajikan salah satu contoh soal uji awal di SMA Negeri 2 Binjai.

Sebuah pesawat terbang pada ketinggian 1,6 km mulai bergerak naik dengan sudut konstan $28^{\circ}$.

a) Bagaimana cara menghitung ketinggian pesawat tersebut dalam waktu 35 detik 
kemudian dengan kecepatan konstan 320 $\mathrm{km} / \mathrm{jam}$ ?

b) Berapa ketinggian pesawat tersebut dalam waktu 35 detik kemudian dengan kecepatan konstan $320 \mathrm{~km} / \mathrm{jam}$ !

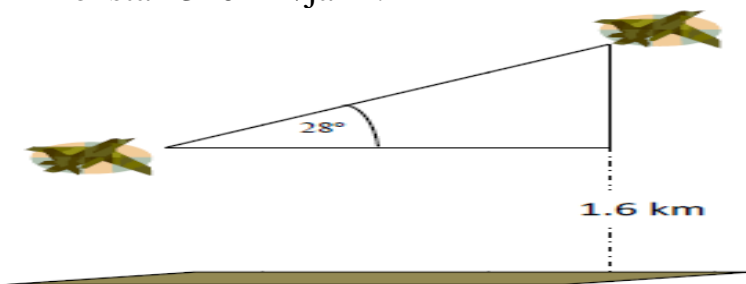

Gambar 3. Contoh soal uji awal di SMA Negeri 2 Binjai

Dari penelitian uji awal yang dilakukan peneliti dilapangan pada tanggal 24 Maret 2019 pada tes kemampuan berpikir kritis dapat dilihat perbandingan antara hasil alternatif jawaban yang benar dengan jawaban yang dibuat siswa. Berikut ini adalah alternatif jawaban yang benar pada contoh soal kemampuan berpikir kritis di atas adalah sebagai berikut:

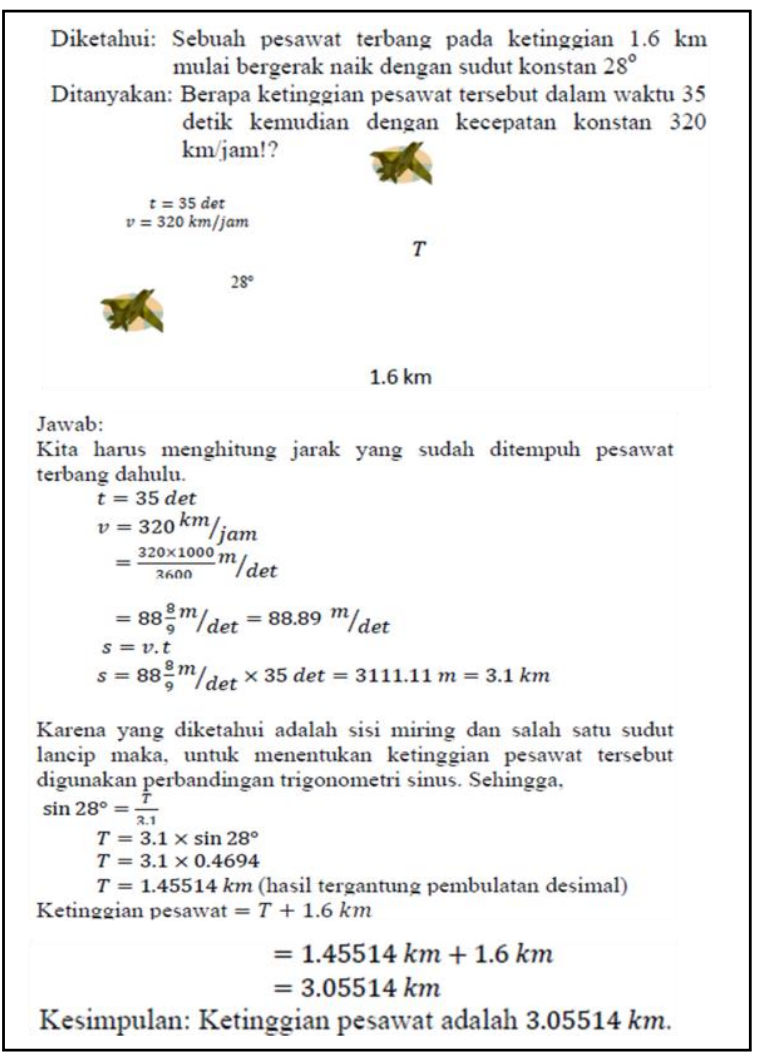

Gambar 4. Alternatif Jawaban yang benar pada contoh soal kemampuan berpikir kritis

Dan berikut ini salah satu contoh jawaban siswa dari persoalan di atas,

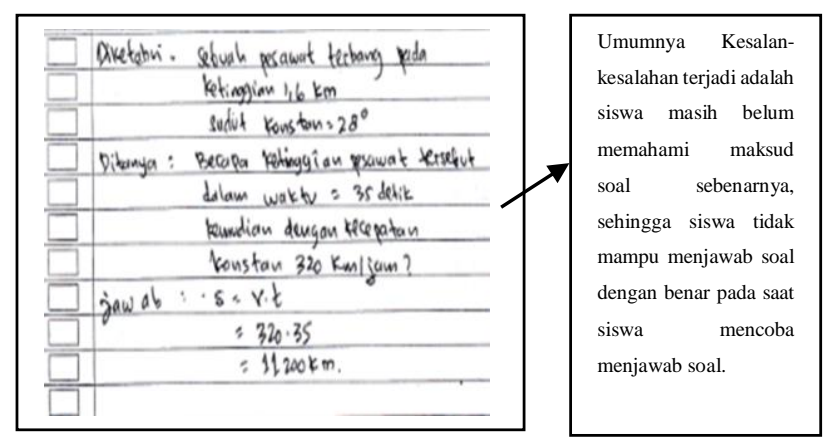

Gambar 5. Salah satu proses penyelesaian jawaban siswa pada tes uji awal kemampuan berpikir kritis siswa

Dari jawaban siswa di atas, terlihat bahwa kemampuan berpikir kritis siswa masih rendah. Hal ini terlihat siswa mencoba menyelesaian soal tersebut, banyak siswa yang mengalami kesulitan untuk menentukan ketinggian pesawat tersebut dalam waktu 35 detik kemudian dengan kecepatan konstan $320 \mathrm{~km} / \mathrm{jam}$. Hal ini juga terlihat tampaknya siswa telah terbiasa belajar matematika dengan cara menghapal rumus-rumus atau prosedur-prosedur rutin dalam menyelesaiakan soal.

Dari 30 siswa yang menjawab soal tersebut hanya 3 siswa yang menjawab soal tersebut (10\%) yang menjawab benar, 19 siswa $(63,3 \%)$ menjawab salah dan 8 siswa $(26,7 \%)$ tidak mampu menjawab sama sekali. Hal ini menunjukkan bahwa kemampuan berpikir kritis siswa masih rendah. Hingga saat ini, pembelajaran untuk meningkatkan Kemampuan Berpikir Kreatif dan Berpikir Kritis siswa belum begitu membudaya di kelas, guru selalu terfokus hanya pada soal-soal rutin yang diberikan sehingga pembelajaran tidak sesuai dengan tuntutan kurikulum 2013, dimana kurikulum 2013 lebih menekankan pada dimensi pedagogik modern dalam pembelajaran, yaitu menggunakan pendekatan ilmiah. Pendekatan ilmiah tersebut meliputi, mengamati, menanya, menalar, mencoba, dan membentuk jejaring.

\section{B. Metode Penelitian}

Penelitian ini dilaksanakan pada kelas X semester 2 tahun ajaran 2018/2019 di SMA Negeri 2 Binjai dengan jadwal yang akan dikoordinasi dengan kegiatan sekolah. Adapun alasan peneliti 
memilih lokasi di SMA Negeri 2 Binjai sebagai berikut:

1. Karena sekolah SMA Negeri 2 Binjai dekat dengan tempat tinggal peneliti sehubungan dengan biaya dan waktu penulis yang terbatas.

2. Sepanjang sepengetahuan peneliti, untuk sampai saat ini belum pernah ada penelitian yang meneliti tentang Perbedaan Kemampuan Berpikir Kreatif dan Berpikir Kritis Siswa yang diajar dengan Pembelajaran Konvensional dan Kontekstual di SMA Negeri 2 Binjai.

Penelitian ini melibatkan dua jenis instrumen yaitu test dan non-test (bukan test). Instrumen dalam bentuk test digunakan untuk mengukur kemampuan berpikir kreatif dan berpikir kritis siswa. Sedangkan instrumen dalam bentuk non-testnya yaitu lembar pengamatan kegiatan belajar siswa (aktivitas siswa). Berikut ini uraian dari kedua jenis instrumen yang dikembangkan:

\section{Test Kemampuan Berpikir Kreatif (Instrumen-1)}

Test untuk mengukur kemampuan berpikir kreatif ini terdiri dari soal dalam bentuk essay agar dapat terlihat sistematisasi alur pikir, kelengkapan, kejelasan dan kelogisan, jawaban, serta ketepatan representainya. Banyaknya butir soal dalam penelitian ini 5 butir soal. Setelah soal disusun, kemudian dilakukan telaah terhadap butir soal secara kualitatif yang bertujuan untuk menguji butir soal dari kesesuaian materi, konstruksi, dan bahasa. Hal ini berkaitan erat dengan validasi isi. Selanjutnya, untuk menjamin validasi isi dilakukan dengan menyusun kisi- kisi soal tes kemampuan berpikir kreatif matematik sebagai berikut:

Tabel 1. Kisi - Kisi Kemampuan Berpikir Kreatif Matematik

\begin{tabular}{|c|c|c|c|c|}
\hline $\begin{array}{c}\text { Jenis } \\
\text { Kemampuan } \\
\text { Berpikir } \\
\text { Kreatif }\end{array}$ & $\begin{array}{c}\text { Materi } \\
\text { Ajar }\end{array}$ & $\begin{array}{c}\text { Indikator } \\
\text { Yang Diukur }\end{array}$ & $\begin{array}{c}\text { Nomor } \\
\text { Soal }\end{array}$ & $\begin{array}{c}\text { Bentuk } \\
\text { Soal }\end{array}$ \\
\hline $\begin{array}{c}\text { Berpikir } \\
\text { lancer } \\
\text { (Fluency) }\end{array}$ & $\begin{array}{c}\text { Geomet } \\
\text { ri }\end{array}$ & $\begin{array}{ll}\text { - } & \text { Menulis } \\
\text { banyak } \\
\text { cara } \\
\text { dalam } \\
\text { menjawab } \\
\text { soal. } \\
\text { - } \\
\text { Menjawab } \\
\text { soal lebih } \\
\text { dari satu } \\
\text { jawaban }\end{array}$ & $1,2,3,4,5$ & Uraian \\
\hline
\end{tabular}

\begin{tabular}{|c|c|c|c|c|}
\hline $\begin{array}{c}\text { Jenis } \\
\text { Kemampuan } \\
\text { Berpikir } \\
\text { Kreatif }\end{array}$ & $\begin{array}{l}\text { Materi } \\
\text { Ajar }\end{array}$ & $\begin{array}{c}\text { Indikator } \\
\text { Yang Diukur }\end{array}$ & $\begin{array}{c}\text { Nomor } \\
\text { Soal }\end{array}$ & $\begin{array}{c}\text { Bentuk } \\
\text { Soal }\end{array}$ \\
\hline $\begin{array}{c}\text { Berpikir luwes } \\
\text { (flexibility) }\end{array}$ & $\begin{array}{c}\text { Geomet } \\
\text { ri }\end{array}$ & $\begin{array}{l}\text { menyatakan } \\
\text { hubungan } \\
\text { sebab akibat } \\
\text { dalam sebuah } \\
\text { permasalahan }\end{array}$ & $1,2,3,4,5$ & Uraian \\
\hline $\begin{array}{c}\text { Berpikir } \\
\text { keaslian } \\
\text { (originality) }\end{array}$ & $\begin{array}{c}\text { Geomet } \\
\text { ri }\end{array}$ & $\begin{array}{l}\text { mengemu } \\
\text { kakan ide- } \\
\text { ide baru } \\
\text { dalam } \\
\text { meyelesai } \\
\text { kan } \\
\text { masalah } \\
\text { - } \\
\text { Memberik } \\
\text { an cara } \\
\text { penyelesai } \\
\text { an lain } \\
\text { dari yang } \\
\text { sudah } \\
\text { biasa }\end{array}$ & $1,2,3,4,5$ & Uraian \\
\hline $\begin{array}{l}\text { Berpikir } \\
\text { elaborasi } \\
\text { (Mengel } \\
\text { aborasi) }\end{array}$ & $\begin{array}{l}\text { Geomet } \\
\text { ri }\end{array}$ & $\begin{array}{l}\text { menerapkan } \\
\text { sebuah } \\
\text { konsep dari } \\
\text { konsep yang } \\
\text { umum } \\
\text { digunakan } \\
\text { dalam } \\
\text { masalah } \\
\text { khusus } \\
\text { termasuk } \\
\text { dalam } \\
\text { kemampuan } \\
\text { memperinci } \\
\text { (elaborasi) }\end{array}$ & $1,2,3,4,5$ & Uraian \\
\hline
\end{tabular}

.Penilaian untuk jawaban kemampuan berpikir kreatif matematik siswa disesuaikan dengan keadaan soal dan hal - hal yang ditanyakan. Adapun pedoman penyekoran didasarkan pada pedoman penilaian rubrik untuk kemampuan berpikir kreatif matematik sebagai berikut:

Tabel 2. Pedoman Penskoran Tes Kemampuan Berpikir Kreatif Siswa

\begin{tabular}{|c|c|c|}
\hline $\begin{array}{c}\text { Aspek Yang } \\
\text { Menjadi } \\
\text { Penilaian Guru }\end{array}$ & Indikator & Skor \\
\hline \multirow{4}{*}{ Kelancaran } & $\begin{array}{l}\text { Jawaban tidak Lengkap atau cara } \\
\text { yang digunakan tidak berhasil }\end{array}$ & 1 \\
\hline & $\begin{array}{l}\text { Paling tidak satu jawaban benar } \\
\text { diberikan dan satu cara } \\
\text { digunakan untuk memecahkan } \\
\text { soal }\end{array}$ & 2 \\
\hline & $\begin{array}{l}\text { Paling tidak dua jawaban benar } \\
\text { diberikan dan dua cara digunakan }\end{array}$ & 3 \\
\hline & $\begin{array}{l}\text { Seluruh jawaban benar dan } \\
\text { beberapa pendekatan/cara dipakai }\end{array}$ & 4 \\
\hline \multirow{5}{*}{$\begin{array}{c}\text { Keluwesan } \\
\text { (Fleksibilitas) }\end{array}$} & Tidak menjawab Soal & 0 \\
\hline & $\begin{array}{l}\text { Menjawab soal dengan salah dan } \\
\text { tidak beragam }\end{array}$ & 2 \\
\hline & $\begin{array}{l}\text { Memberikan jawaban soal yang } \\
\text { tidak beragam namun benar }\end{array}$ & 4 \\
\hline & $\begin{array}{l}\text { Memberikan jawaban yang } \\
\text { beragam tetapi salah }\end{array}$ & 6 \\
\hline & $\begin{array}{l}\text { Memberikan jawaban yang } \\
\text { beragam dan benar }\end{array}$ & 8 \\
\hline
\end{tabular}




\begin{tabular}{|c|l|c|}
\hline $\begin{array}{c}\text { Keaslian } \\
\text { (originality) }\end{array}$ & $\begin{array}{l}\text { Cara/Prosedur yang digunakan } \\
\text { bukan merupakan solusi } \\
\text { pemecahan masalah }\end{array}$ & 2 \\
\cline { 2 - 3 } & $\begin{array}{l}\text { Cara yang dipakai merupakan } \\
\text { solusi pemecahan masalah, } \\
\text { namun yang digunakan } \\
\text { merupakan solusi umum }\end{array}$ & 4 \\
\cline { 2 - 3 } & $\begin{array}{l}\text { Cara yang digunakan tidak lazim } \\
\text { digunakan dan berhasil dalam } \\
\text { menyelesaikan masalah. Cara } \\
\text { yang digunakan oleh satu orang }\end{array}$ & 6 \\
\cline { 2 - 3 } (Mengelaborasi) & $\begin{array}{l}\text { Cara yang digunakan berbeda } \\
\text { dari yang umum dan menarik } \\
\text { serta berhasil dalam memecahkan } \\
\text { masalah. Cara yang digunakan } \\
\text { lebih dari satu orang. }\end{array}$ & 7 \\
\cline { 2 - 3 } & $\begin{array}{l}\text { Sedikit atau tidak ada penjelasan } \\
\text { eangkah-langkah pemecahan } \\
\text { masalah yang tidak akurat dan } \\
\text { hasilnya salah }\end{array}$ & 0 \\
\cline { 2 - 3 } & $\begin{array}{l}\text { Langkah-langkah pemecahan } \\
\text { masalah yang tidak akurat namun } \\
\text { hasil yang diberikan benar }\end{array}$ & 2 \\
\cline { 2 - 3 } & $\begin{array}{l}\text { Langkah-langkah pemecahan } \\
\text { masalah akurat tetapi hasil salah }\end{array}$ & 3 \\
\cline { 2 - 3 } & $\begin{array}{l}\text { Langkah - langkah pemecahan } \\
\text { masalah akurat dan memberikan } \\
\text { hasil yang benar }\end{array}$ & 4 \\
\hline
\end{tabular}

Sebelum digunakan instrument ini dalam penelitian terlebih dahulu diujicobakan untuk mengetahui sejauh mana instrument yang disusun dapat mengukur apa yang seharusnya diukur dan seberapa jauh keterandalannya. Setelah diujicobakan hasil uji coba dianalisis secara statistic untuk mengetahui realibilitas dan validitas setiap soal. Tujuan analisis untuk melihat apakah soal yang diujicobakan reliable dan valid untuk menjadi instrument dalam penelitian ini.

\section{Test Kemampuan Berpikir Kritis (Instrumen-II)}

Menurut Arikunto (2011:162) mengatakan bahwa soal-soal berbentuk esai (uraian) biasanya jumlahnya tidak banyak, hanya sekitar 5-10 buah soal dalam waktu kira-kira 90 s.d 120 menit. Berdasarkan pendapat Arikunto maka tes kemampuan berpikir kritis pada penelitian ini terdiri dari 10 soal berbentuk uraian. Dipilih tes berbentuk uraian tersebut, karena dengan tes berbentuk uraian dapat diketahui proses pengerjaan siswa dalam menyelesaikan soal matematika, dengan demikian diharapkan dapat dengan tepat diidentifikasi tingkat kemampuan siswa berdasarkan jenjang kognitif yang dicapai siswa.

Kriteria pemberian skor setiap butir soal dalam tes penelitian ini berdasarkan pedoman penskoran soal - soal, dimana tiap butir soal mempunyai bobot nilai maksimal 4 (empat) dan minimal 0 (nol). Adapun criteria penskorannya mengacu pada teknik penskoran Hancock (1995), yaitu:

Jawaban diberi nilai 4, apabila:

$>$ Jawaban komplit dan benar untuk pertanyaan yang diberikan

$>$ Illustrasi keterampilan pemecahan masalah, penalaran, dan komunikasi yang sempurna

$>$ Jika jawaban terbuka, jawaban semuanya benar.

$>$ Pekerjaannya ditunjukkan dan atau dijelaskan (clearly)

$>$ Memuat sedikit kesalahan

Jawaban diberi nilai 3, jika :

$>$ Jika jawaban terbuka, banyak jawaban yang benar

> Jawaban benar untuk soal yang diberikan

> Illustrasi keterampilan pemecahan masalah, penalaran dan komunikasi yang baik

$>$ Pekerjaan ditunjukkan dan atau dijelaskan

$>$ Memuat beberapa kesalahan dalam matematika

Jawaban diberi skor 2, apabila :

$>$ Penyimpulan terlihat tidak akurat

$>$ Kekurangan dalam berpikir kritis tingkat tinggi terlihat jelas

$>$ Beberapa jawaban dari soal tidak lengkap

$>$ Illustrasi ketrampilan pemecahan masalah, penarikan dan komunikasi yang cukup

$>$ Banyak kesalahan dari penalaran matematika yang muncul

$>$ Muncul beberapa keterbatasan dalam pemahaman konsep matematika

Jawaban diberi skor 1 jika:

$>$ Banyak terjadi kesalahan perhitungan matematika yang muncul

$>$ Muncul masalah dalam meniru ide matematika tetapi tidak dikembangkan

$>$ Keterampilan pemecahan masalah, penalaran dan atau komunikasi kurang (poor).

$>$ Terdapat sedikit pemahaman matematika yang diilustrasikan

$>$ Siswa jarang mencoba beberapa hall

Jawaban diberi nilai 0, apabila :

$>$ Keseluruhan jawaban tidak ada atau tidak tampak

$>$ Tidak muncul ketrampilan pemecahan masalah 
Sama sekali pemahaman matematikanya tidak muncul

$>$ Tidak menjawab semua kemungkinan yang diberikan

$>$ Terlihat dengan jelas mencoba - coba atau sekedar menebak jawaban

Sebelum digunakan instrumen ini dalam penelitian terlebih dahulu diujicobakan untuk mengetahui sejauh mana instrument yang disusun dapat mengukur apa yang seharusnya diukur dan seberapa jauh keterandalannya. Setelah diujicobakan hasil uji coba dianalisis secara statistik untuk mengetahui reabilitas dan validitas setiap soal. Tujuan analisis untuk melihat apakah soal yang diujicobakan reliable dan valid untuk menjadi instrument dalam penelitian ini.

Pada tahap perancangan (design) dalam penelitian ini disebut Draft-I. Perangkat pembelajaran yang akan dihasilkan adalah rencana pelaksanaan pembelajaran (RPP), buku guru (BG), buku siswa (BS), Lembar Aktivitas Siswa (LAS) dan tes kemampuan hasil belajar (THB). Kegiatan dalam tahap ini meliputi: penyusunan tes, pemilihan media, pemilihan format, dan perancangan awal.

\section{1) Penyusunan tes}

Dasar penyusunan tes adalah analisis spesifikasi tujuan pembelajaran yang dijabarkan dalam indikator pencapaian hasil belajar. Tes yang dimaksud adalah tes kemampuan hasil belajar (THB) pada pokok bahasan Geometri Bidang Datar. Prosedur penyusunan tes adalah sebagai berikut:

a) Penentuan tujuan pembelajaran yang dijabarkan dalam indikator pencapaian hasil belajar.

b) Penentuan kisi-kisi tes

c) Penyusunan tes

d) Penentuan pedoman penskoran. Penskoran yang digunakan adalah Penilaian Acuan Patokan (PAP), karena PAP beroreantasi pada tingkat kemampuan siswa terhadap materi yang diteskan, sehingga skor yang diperoleh mencerminkan persentase kemampuan.

\section{2) Pemilihan media}

Kegiatan ini bertujuan untuk memilih media yang tepat dan sesuai dengan isi pelajaran, yaitu penyesuaian antara analisis materi, dan analisis tugas. Media yang digunakan berupa papan tulis, alat tulis dan media cetak berupa LAS

\section{3) Pemilihan format}

Tahap ini bertujuan untuk memilih format yang sesuai dengan faktor-faktor yang telah dijabarkan dalam kompetensi dasar, yaitu format untuk mendesain isi pembelajaran, strategi, metode pembelajaran dan sumber pembelajaran yang akan dikembangkan. Isi pembelajaran mengacu pada hasil analisis materi, hasil analisis tugas dan indikator hasil belajar yang telah dirumuskan pada tahap pendefinisian. Strategi pembelajaran yang akan digunakan yaitu siswa aktif belajar melalui penerapan pembelajaran kontekstual dan pembelajaran konvensional. Metode pembelajaran yang digunakan yaitu ceramah, demonstrasi dan latihan. Sumber belajar yang akan dikembangkan terdiri dari buku petunjuk guru dan Lembar Aktivitas Siswa (LAS).

\section{4) Perancangan Awal}

Perancangan awal perangkat pembelajaran dan instrumen penelitian meliputi: Rencana Pelaksanaan Pembelajaran (RPP), Buku Guru (BG), Lembar aktivitas Siswa (LAS), tes kemampuan berpikir kreatif dan berpikir kritis.

\section{Hasil dan Pembahasan}

Tabel 3. Hasil Analisis Pretest Kemampuan Berpikir Kreatif dan Berpikir Kritis Matematika Siswa

\begin{tabular}{|c|c|c|c|c|c|c|c|c|}
\hline \multirow{2}{*}{ Test } & \multicolumn{3}{|c|}{ Kontekstual } & \multicolumn{4}{c|}{ Konvensional } \\
\cline { 2 - 8 } & $x_{\text {min }}$ & $x_{\text {mak }}$ & $\bar{x}$ & & $x_{\text {min }}$ & $x_{\text {mak }}$ & - & ${ }^{\circ}$ \\
\hline $\begin{array}{c}\text { Berpikir } \\
\text { Kreatif }\end{array}$ & 30 & 42 & 35,5 & 2,4 & 29 & 42 & 34,2 & 2,63 \\
\hline $\begin{array}{c}\text { Berpikir } \\
\text { Kritis }\end{array}$ & 38 & 49 & 44,6 & 2,6 & 37 & 52 & 44,13 & 3,05 \\
\hline
\end{tabular}

Pada Tabel 3 terlihat jelas bahwa rerata pretest kemampuan berpikir kreatif dan berpikir kritis matematika pada kelompok pembelajaran kontekstual dan konvensional berbeda

Tabel 4. Pretest Kemampuan Berpikir Kreatif Matematika Siswa pada Kelompok Pembelajaran Kontekstual Secara Kuantitatif

\begin{tabular}{|c|c|c|c|c|}
\hline No & $\begin{array}{c}\text { Interval } \\
\text { Nilai }\end{array}$ & $\begin{array}{c}\text { Jumalah } \\
\text { Siswa }\end{array}$ & Persentase & $\begin{array}{c}\text { Kategori } \\
\text { Penilaian }\end{array}$ \\
\hline 1 & $\begin{array}{c}0 \leq \text { SKBK }< \\
45\end{array}$ & 30 & $100 \%$ & Sangat Kurang \\
\hline 2 & $\begin{array}{c}45 \leq \text { SKBK } \\
65\end{array}$ & 0 & $0 \%$ & Kurang \\
\hline
\end{tabular}




\begin{tabular}{|c|c|c|c|c|}
\hline No & $\begin{array}{c}\text { Interval } \\
\text { Nilai }\end{array}$ & $\begin{array}{c}\text { Jumalah } \\
\text { Siswa }\end{array}$ & Persentase & $\begin{array}{c}\text { Kategori } \\
\text { Penilaian }\end{array}$ \\
\hline 3 & $\begin{array}{c}65 \leq \text { SKBK }< \\
75\end{array}$ & 0 & $0 \%$ & Cukup \\
\hline 4 & $\begin{array}{c}75 \leq \text { SKBK }< \\
90\end{array}$ & 0 & $0 \%$ & Baik \\
\hline 5 & $\begin{array}{c}90 \leq \mathrm{SKBK} \leq \\
100\end{array}$ & 0 & $0 \%$ & Sangat Baik \\
\hline
\end{tabular}

Tabel 5. Pre-test Kemampuan Berpikir Kreatif Matematika Siswa pada Kelompok Pembelajaran Konvensional Secara Kuantitatif

\begin{tabular}{|c|c|c|c|c|}
\hline No & Interval Nilai & $\begin{array}{c}\text { Jumalah } \\
\text { Siswa }\end{array}$ & Persentase & $\begin{array}{c}\text { Kategori } \\
\text { Penilaian }\end{array}$ \\
\hline 1 & $\begin{array}{c}0 \leq \mathrm{SKBK}< \\
45\end{array}$ & 30 & $100 \%$ & Sangat Kurang \\
\hline 2 & $\begin{array}{c}45 \leq \mathrm{SKBK}< \\
65\end{array}$ & 0 & $0 \%$ & Kurang \\
\hline 3 & $\begin{array}{c}65 \leq \mathrm{SKBK}< \\
75\end{array}$ & 0 & $0 \%$ & Cukup \\
\hline 4 & $\begin{array}{c}75 \leq \mathrm{SKBK}< \\
90\end{array}$ & 0 & $0 \%$ & Baik \\
\hline 5 & $\begin{array}{c}90 \leq \mathrm{SKBK} \leq \\
100\end{array}$ & 0 & $0 \%$ & Sangat Baik \\
\hline
\end{tabular}

Dari tabel 4 dan Tabel 5 menunjukkan bahwa, kemampuan berpikir kreatif pada kedua kelompok hampir sama, dalam hal ini masih banyak siswa yang berada di bawah kategori Kriteria Ketuntasan Minimal (KKM) yaitu : $\leq 65$, sehingga dapat disimpulkan pada kelompok pembelajaran kontekstual terdapat $100 \%$ yang berada di bawah KKM, demikian pula dengan kelompok pembelajaran konvensional yaitu 100 $\%$. Dalam hal ini, kemampuan berpikir kreatif matematika siswa pada kelompok pembelajaran kontekstual sama saja dengan kelompok pembelajaran konvensional. Untuk lebih jelasnya dapat dicermati Gambar 7 yang merangkum hasil pretest kemampuan berpikir kreatif matematika siswa pada masing-masing kelompok berikut ini

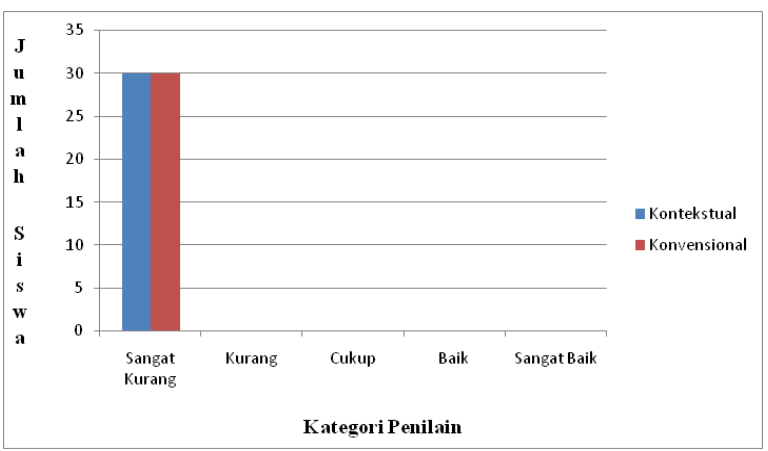

Gambar 6. Hasil pretest kemampuan berpikir kreatif matematika siswa
Tabel 6. Pretest Kemampuan Berpikir Kritis Matematika Siswa pada Kelompok Pembelajaran Kontekstual Secara Kuantitatif

\begin{tabular}{|c|c|c|c|c|}
\hline No & Interval Nilai & $\begin{array}{c}\text { Jumalah } \\
\text { Siswa }\end{array}$ & Persentase & $\begin{array}{c}\text { Kategori } \\
\text { Penilaian }\end{array}$ \\
\hline 1 & $\begin{array}{c}0 \leq \mathrm{SKBK}< \\
45\end{array}$ & 13 & $43,3 \%$ & Sangat Kurang \\
\hline 2 & $\begin{array}{c}45 \leq \mathrm{SKBK}< \\
65\end{array}$ & 17 & $56,7 \%$ & Kurang \\
\hline 3 & $\begin{array}{c}65 \leq \mathrm{SKBK}< \\
75\end{array}$ & 0 & $0 \%$ & Cukup \\
\hline 4 & $\begin{array}{c}75 \leq \mathrm{SKBK}< \\
90\end{array}$ & 0 & $0 \%$ & Baik \\
\hline 5 & $\begin{array}{c}90 \leq \mathrm{SKBK} \leq \\
100\end{array}$ & 0 & $0 \%$ & Sangat Baik \\
\hline
\end{tabular}

Tabel 7 Pretest Kemampuan Berpikir Kritis Matematika Siswa pada Kelompok Pembelajaran Konvensional Secara Kuantitatif

\begin{tabular}{|c|c|c|c|c|}
\hline No & Interval Nilai & $\begin{array}{c}\text { Jumalah } \\
\text { Siswa }\end{array}$ & Persentase & $\begin{array}{c}\text { Kategori } \\
\text { Penilaian }\end{array}$ \\
\hline 1 & $\begin{array}{c}0 \leq \text { SKBK }< \\
45\end{array}$ & 15 & $50 \%$ & Sangat Kurang \\
\hline 2 & $\begin{array}{c}45 \leq \text { SKBK }< \\
65\end{array}$ & 15 & $50 \%$ & Kurang \\
\hline 3 & $\begin{array}{c}65 \leq \text { SKBK }< \\
75\end{array}$ & 0 & $0 \%$ & Cukup \\
\hline 4 & $\begin{array}{c}75 \leq \text { SKBK }< \\
90\end{array}$ & 0 & $0 \%$ & Baik \\
\hline 5 & $\begin{array}{c}90 \leq \text { SKBK } \leq \\
100\end{array}$ & 0 & $0 \%$ & Sangat Baik \\
\hline
\end{tabular}

Dari tabel 6 dan Tabel 7 menunjukkan bahwa, kemampuan berpikir kritis pada kedua kelompok hampir sama, dalam hal ini masih banyak siswa yang berada di bawah kategori Kriteria Ketuntasan Minimal (KKM) yaitu : $\leq 65$, sehingga dapat disimpulkan pada kelompok pembelajaran kontekstual terdapat $100 \%$ yang berada di bawah KKM, demikian pula dengan kelompok pembelajaran konvensional yaitu $100 \%$. Dalam hal ini, kemampuan berpikir kritis matematika siswa pada kelompok pembelajaran kontekstual sama saja dengan kelompok pembelajaran konvensional. Untuk lebih jelasnya dapat dicermati Gambar 8 yang merangkum hasil pretest kemampuan berpikir kritis matematika siswa pada masing-masing kelompok berikut ini. 


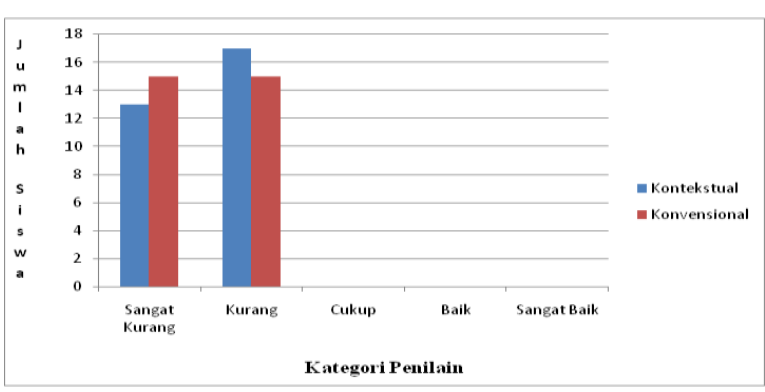

Gambar 7. Hasil pretest kemampuan berpikir kritis matematika siswa

Tabel 8. Pengujian Perbedaan Rerata Kemampuan Berpikir Kreatif dan Kemampuan Berpikir Kritis Matematik Siswa Kelompok Pembelajaran Kontekstual dan Pembelajaran Konvensional

\begin{tabular}{|l|c|c|c|c|}
\hline \multicolumn{1}{|c|}{ Aspek } & Kelompok & $\boldsymbol{t}$ hitung & $\boldsymbol{t}$ tabel & Kesimpulan \\
\hline Kemampuan & Kontekstual & \multirow{2}{*}{1,963} & 2,002 & $\begin{array}{l}\text { Tidak Ada } \\
\text { Berpikir Kreatif }\end{array}$ \\
\cline { 2 - 3 } & Konvensional & & & Perbedaan \\
\hline $\begin{array}{l}\text { Kemampuan } \\
\text { Berpikir Kritis }\end{array}$ & Kontekstual & \multirow{2}{*}{0,639} & 2,002 & $\begin{array}{l}\text { Tidak Ada } \\
\text { Kerbedaan }\end{array}$ \\
\cline { 2 - 3 } & Konvensional & & & \\
\hline
\end{tabular}

Berdasarkan hasil pengolahan pada Tabel 8 di atas, data skor pretes kemampuan berpikir kreatif dan kemampuan berpikir kritis matematika siswa menghasilkan $t$ hitung $=1,963$ (untuk kemampuan berpikir kreatif) dan 0,639 (untuk kemampuan berpikir kritis) serta $t_{\text {tabel }}=2,002$, jadi $t$ hitung dalam daerah penerimaan maka Ho diterima. Ini berarti tidak terdapat perbedaan yang signifikan kemampuan berpikir kreatif antara kelompok pembelajaran kontekstual dengan kelompok pembelajaran konvensional. Dengan kata lain, kemampuan berpikir kreatif dan kemampuan berpikir kritis matematika siswa pada kedua kelompok tidak berbeda sebelum diberikan perlakuan.

Tabel 9. Hasil Analisis Postes Kemampuan Berpikir Kreatif dan Kemampuan Berpikir Kritis

\begin{tabular}{|c|c|c|c|c|c|c|c|c|}
\hline \multirow{2}{*}{ Tes } & \multicolumn{5}{|c|}{ Kontekstual } & \multicolumn{4}{|c|}{ Konvensional } \\
\cline { 2 - 9 } & $\boldsymbol{x}_{\text {min }}$ & $\boldsymbol{x}_{\text {maks }}$ & $\overline{\boldsymbol{X}}$ & $\boldsymbol{s}$ & $\boldsymbol{x}_{\text {min }}$ & $\boldsymbol{x}_{\text {mats }}$ & $\overline{\boldsymbol{X}}$ & $\boldsymbol{s}$ \\
\hline $\begin{array}{c}\text { Kemampuan } \\
\text { Berpikir } \\
\text { Kreatif }\end{array}$ & 50 & 86 & 73,4 & 8,56 & 42 & 66 & 53,83 & 6,84 \\
\hline $\begin{array}{c}\text { Kemampuan } \\
\text { Berpikir } \\
\text { Kritis }\end{array}$ & 58 & 75 & 66,56 & 3,75 & 50 & 80 & 69,3 & 7,08 \\
\hline
\end{tabular}

Pada tabel 9 terlihat jelas bahwa rerata postes kemampuan berpikir kreatif dan kemampuan berpikir kritis matematika siswa pada kelompok pembelajaran kontekstual dan kelompok pembelajaran konvensional hampir tidak berbeda. Secara kuantitatif, hasil postes kemampuan berpikir kreatif dan berpikir kritis pada masing-masing pembelajaran dapat dilihat pada Tabel 10 berikut ini:

Tabel 10. Postes Kemampuan Berpikir Kreatif Matematika Siswa pada Kelompok Pembelajaran Kontekstual Secara Kuantitatif

\begin{tabular}{|c|c|c|c|c|}
\hline No. & Interval Nilai & Jumlah Siswa & Persentase & $\begin{array}{c}\text { Kategori } \\
\text { Penilaian }\end{array}$ \\
\hline 1 & $0 \leq \mathrm{SPKM}<45$ & 0 & $0 \%$ & Sangat Kurang \\
\hline 2 & $45 \leq \mathrm{SPKM}<65$ & 3 & $10 \%$ & Kurang \\
\hline 3 & $65 \leq \mathrm{SPKM}<75$ & 16 & $53,3 \%$ & Cukup \\
\hline 4 & $75 \leq \mathrm{SPKM}<90$ & 11 & $36,7 \%$ & Baik \\
\hline 5 & $90 \leq \mathrm{SPKM} \leq 100$ & 0 & $0 \%$ & Sangat Baik \\
\hline
\end{tabular}

Tabel 11. Postes Kemampuan Berpikir Kreatif Matematika Siswa pada Kelompok Pembelajaran Konvensional Secara Kuantitatif

\begin{tabular}{|c|c|c|c|c|}
\hline No. & Interval Nilai & Jumlah Siswa & Persentase & $\begin{array}{c}\text { Kategori } \\
\text { Penilaian }\end{array}$ \\
\hline 1 & $0 \leq \mathrm{SPKM}<45$ & 5 & $16,7 \%$ & Sangat Kurang \\
\hline 2 & $45 \leq \mathrm{SPKM}<65$ & 24 & $80 \%$ & Kurang \\
\hline 3 & $65 \leq \mathrm{SPKM}<75$ & 1 & $3,3 \%$ & Cukup \\
\hline 4 & $75 \leq \mathrm{SPKM}<90$ & 0 & $0 \%$ & Baik \\
\hline 5 & $90 \leq \mathrm{SPKM} \leq 100$ & 0 & $0 \%$ & Sangat Baik \\
\hline
\end{tabular}

Dari Tabel 10 dan Tabel 11 menunjukkan bahwa kemampuan berpikir kreatif pada kedua kelompok berbeda, dalam hal ini masih banyak siswa yang berada di bawah kategori Kriteria Ketuntasan Minimal (KKM) yaitu $\leq 65$, sehingga dapat disimpulkan pada kelompok pembelajaran kontekstual terdapat $10 \%$ yang berada di bawah KKM, demikian pula dengan kelompok pembelajaran konvensional yaitu 96,7 \%. Dalam hal ini, kemampuan berpikir kreatif pada kelompok pembelajaran kontekstual lebih baik dari pada kelompok pembelajaran konvensional. Untuk lebih jelasnya dapat dicermati Gambar 9 yang merangkum hasil postes kemampuan berpikir kreatif pada masing-masing kelompok berikut ini. 


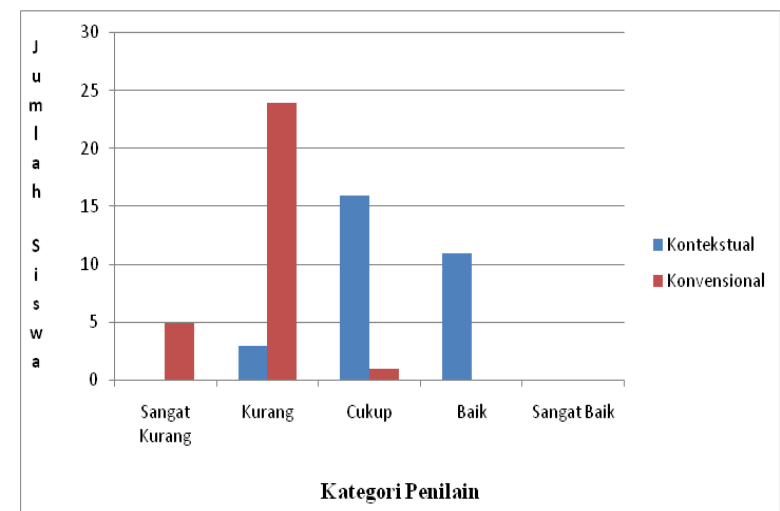

Gambar 8. Hasil Postes Kemampuan Berpikir Kreatif

Tabel 12. Postes Kemampuan Berpikir Kritis pada Kelompok Pembelajaran Kontekstual Secara Kuantitatif

\begin{tabular}{|c|c|c|c|c|}
\hline No. & Interval Nilai & $\begin{array}{c}\text { Jumlah } \\
\text { Siswa }\end{array}$ & Persentase & $\begin{array}{c}\text { Kategori } \\
\text { Penilaian }\end{array}$ \\
\hline 1 & $0 \leq$ SPKM $<45$ & 0 & $0 \%$ & Sangat Kurang \\
\hline 2 & $\begin{array}{c}45 \leq \text { SPKM }< \\
65\end{array}$ & 6 & $20 \%$ & Kurang \\
\hline 3 & $\begin{array}{c}65 \leq \text { SPKM }< \\
75\end{array}$ & 21 & $70 \%$ & Cukup \\
\hline 4 & $\begin{array}{c}75 \leq \text { SPKM }< \\
90\end{array}$ & 3 & $10 \%$ & Baik \\
\hline 5 & $\begin{array}{c}90 \leq \text { SPKM } \leq \\
100\end{array}$ & 0 & $0 \%$ & Sangat Baik \\
\hline
\end{tabular}

Tabel 13. Postes Kemampuan Berpikir Kritis pada Kelompok Pembelajaran Konvensional Secara Kuantitatif

\begin{tabular}{|c|c|c|c|c|}
\hline No. & Interval Nilai & $\begin{array}{c}\text { Jumlah } \\
\text { Siswa }\end{array}$ & Persentase & $\begin{array}{c}\text { Kategori } \\
\text { Penilaian }\end{array}$ \\
\hline 1 & $0 \leq \mathrm{SPKM}<45$ & 0 & $0 \%$ & Sangat Kurang \\
\hline 2 & $45 \leq \mathrm{SPKM}<65$ & 6 & $20 \%$ & Kurang \\
\hline 3 & $65 \leq \mathrm{SPKM}<75$ & 16 & $53,3 \%$ & Cukup \\
\hline 4 & $75 \leq \mathrm{SPKM}<90$ & 8 & $26,7 \%$ & Baik \\
\hline 5 & $90 \leq \mathrm{SPKM} \leq 100$ & 0 & $0 \%$ & Sangat Baik \\
\hline
\end{tabular}

Dari Tabel 12 dan Tabel 13 menunjukkan bahwa kemampuan berpikir kritis matematika siswa pada kedua kelompok hampir sama, dalam hal ini masih banyak siswa yang berada dibawah kategori Kriteria Ketuntasan Minimal (KKM) yaitu $\leq 65$, sehingga dapat disimpulkan pada kelompok pembelajaran kontekstual terdapat 20 $\%$ yang berada dibawah KKM, demikian pula dengan kelompok konvensional yaitu $20 \%$ juga. Dalam hal ini, kemampuan berpikir kritis siswa pada kelompok pembelajaran kontekstual sama saja dengan kelompok pembelajaran konvensional. Untuk lebih jelasnya dapat dicermati Gambar 10 yang merangkum hasil postes kemampuan berpikir kritis pada masingmasing kelompok berikut ini.

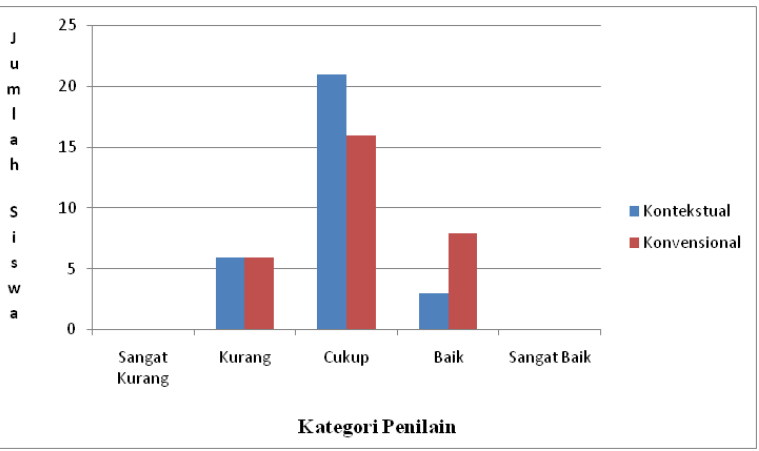

Gambar 10. Hasil Postes Kemampuan Berpikir Kritis

Tabel 14. Kadar Aktivitas Siswa Kelompok Pembelajaran Kontekstual

\begin{tabular}{|c|c|c|c|c|c|c|}
\hline \multirow[b]{2}{*}{ Aspek yang diamati } & \multicolumn{4}{|c|}{ Pertemuan } & \multirow{2}{*}{$\bar{x}$} & \multirow[b]{2}{*}{$\begin{array}{l}\text { Acuan Toleransi } \\
\text { (PWI) }\end{array}$} \\
\hline & 1 & 2 & 3 & 4 & & \\
\hline $\begin{array}{l}\text { Mendengarkan/me mperhatikan } \\
\text { penjelasan gurutteman }\end{array}$ & 20.7 & 19,3 & 24.6 & 27.6 & 23,05 & ${ }_{15 \%} \leq_{25 \%} \leq$ \\
\hline $\begin{array}{l}\text { Membaca (buku yang relevan/buku } \\
\text { siswa dan membaca LAS) }\end{array}$ & 18.7 & 15.4 & 19.3 & 12.4 & 16.45 & ${ }_{10 \%} \leq_{20 \%} \leq$ \\
\hline $\begin{array}{c}\text { Menulis (menyelesaikan } \\
\text { masala/mempresentasikan hasil kerja, } \\
\text { rangkuman/kesimpulan, hal-hal yang } \\
\text { penting }\end{array}$ & 30.7 & 31.8 & 32.8 & 26.5 & 30.45 & ${ }_{30 \%} \leq_{\mathrm{PWI}} \leq$ \\
\hline $\begin{array}{c}\text { Berdiskusi/bertanya antara siswa } \\
\text { dengan temannya, dan antara siswa } \\
\text { dengan guru }\end{array}$ & 20.5 & 23.3 & 28.4 & 38.3 & 27.6 & ${ }_{25 \%} \leq_{35 \%} \leq$ \\
\hline $\begin{array}{l}\text { Perilaku siswa yang tidak relevan } \\
\text { dengan KBM (mengganggu } \\
\text { teman/permisi dari kelas) }\end{array}$ & 1.4 & 9.4 & 2.9 & 1.5 & 3.8 & ${ }_{0 \%} \leq \leq_{\mathrm{PWI}} \leq$ \\
\hline
\end{tabular}

Dari tabel 14 menunjukkan bahwa Persentase kegiatan mendengarkan sebesar 23,05 merupakan proporsi waktu yang baik bagi siswa dengan batas toleransi aktivitas yang ditetapkan sebesar $15 \% \leq$ PWI $\leq 25 \%$. Hal ini menunjukkan adanya minat siswa untuk mendengarkan penjelasan dari guru bahkan sesama siswa . Pada Kegiatan membaca memiliki rerata sebesar 16.45, hal tersebut merupakan proporsi waktu yang baik bagi siswa dengan batas toleransi yang sudah ditentukan yaitu $10 \% \leq \mathrm{PWI} \leq 20 \%$. Hal tersebut menunjukkan bahwa siswa cenderung aktif dalam membaca buku siswa maupun LAS hal ini memungkinkan kesiapan siswa dalam belajar dari rumah sudah cukup baik.

Selanjutnya pada kategori menulis memiliki rata-rata 30.45 merupakan proporsi waktu yang cukup baik bagi siswa dengan batas toleransi yang sudah ditetapkan yaitu $30 \% \leq \mathrm{PWI}$ $\leq 40 \%$. Hal ini menunjukkan bahwa menulis merupakan hal yang biasa saja dalam menyelesaikan masalah, sehingga siswa 
cenderung mengemukakan ide mereka pada lembar kertas. Pada kategori berdiskusi, rerata yang diperoleh sebesar 27.6 merupakan proporsi waktu yang cukup baik bagi bagi siswa dengan batas toleransi yang sudah ditetapkan yaitu $25 \%$ $\leq \mathrm{PWI} \leq 35 \%$. Hal tersebut menunjukkan bahwa siswa sudah mulai dapat menemukan makna berdiskusi dengan baik, dimana tidak ditemukan lagi beberapa siswa yang beranggapan bahwa siswa pintar menjadi ketua kelompok diskusi dan mengerjakan sendiri tanpa menayakan pendapat siswa yang lain. Demikian juga dengan kategori perilaku siswa yang tidak relevan, nilai rataratanya yaitu 3.8 , merupakan proporsi waktu yang baik bagi siswa dengan batas toleransi yang sudah ditetapkan yaitu $0 \% \leq$ PWI $\leq 5 \%$. Hal ini menegaskan bahwa selama kegiatan pembelajaran kontekstual berlangsung tidak begitu terlihat jelas siswa yang meminta izin keluar ruangan, ataupun perilaku siswa yang mengganggu temannya.

\section{Tabel 15. Kadar Aktivitas Siswa Kelompok Pembelajaran Konvensional}

\begin{tabular}{|c|c|c|c|c|c|c|}
\hline \multirow[b]{2}{*}{ Aspek yang diamati } & \multicolumn{4}{|c|}{ Pertemuan } & \multirow{2}{*}{$\begin{array}{c}\bar{x} \\
(\mathbf{P W I})\end{array}$} & \multirow{2}{*}{$\begin{array}{c}\text { Acuan } \\
\text { Toleransi } \\
\text { (PWI) }\end{array}$} \\
\hline & 1 & 2 & 3 & 4 & & \\
\hline $\begin{array}{l}\text { Mendengarkan/memperhat } \\
\text { ikan penjelasan } \\
\text { guru/teman }\end{array}$ & 21.7 & 17,3 & 24.6 & 25.6 & 22.3 & $\begin{array}{c}15 \% \leq_{\mathrm{PWI}} \\
\leq_{25 \%}\end{array}$ \\
\hline $\begin{array}{l}\text { Membaca (buku yang } \\
\text { relevan/buku siswa dan } \\
\text { membaca LAS) }\end{array}$ & 18.5 & 15.4 & 19.3 & 13.4 & 16.65 & $\begin{array}{c}10 \% \leq_{\mathrm{PWI}} \\
\leq_{20 \%}\end{array}$ \\
\hline $\begin{array}{l}\text { Menulis (menyelesaikan } \\
\text { masala/mempresentasikan } \\
\text { hasil kerja, } \\
\text { rangkuman/kesimpulan, } \\
\text { hal-hal yang penting }\end{array}$ & 31.7 & 32.8 & 32.5 & 26.5 & 30.9 & $\begin{array}{c}30 \% \leq \mathrm{PWI} \\
\leq{ }_{40 \%}\end{array}$ \\
\hline $\begin{array}{c}\text { Berdiskusi/bertanya antara } \\
\text { siswa dengan temannya, } \\
\text { dan antara siswa dengan } \\
\text { guru }\end{array}$ & 21.5 & 22.3 & 28.4 & 39.5 & 27.9 & $\begin{array}{c}{ }_{25 \%} \leq_{\mathrm{PWI}} \\
\leq_{35 \%}\end{array}$ \\
\hline $\begin{array}{l}\text { Perilaku siswa yang tidak } \\
\text { relevan dengan KBM } \\
\text { (mengganggu } \\
\text { teman/permisi dari kelas) }\end{array}$ & 2.4 & 9.4 & 2.9 & 2.5 & 4.3 & $\begin{aligned} 0 \% & \leq \\
& \leq{ }_{\mathrm{PWI}}\end{aligned}$ \\
\hline
\end{tabular}

Dari tabel 15 menunjukkan bahwa Persentase kegiatan mendengarkan sebesar 23,3 merupakan proporsi waktu yang baik bagi siswa dengan batas toleransi aktivitas yang ditetapkan sebesar $15 \% \leq$ PWI $\leq 25 \%$. Hal ini menunjukkan adanya minat siswa untuk mendengarkan penjelasan dari guru bahkan sesama siswa . Pada Kegiatan membaca memiliki rerata sebesar 16.65, hal tersebut merupakan proporsi waktu yang baik bagi siswa dengan batas toleransi yang sudah ditentukan yaitu $10 \% \leq$ PWI $\leq 20 \%$. Hal tersebut menunjukkan bahwa siswa cenderung aktif dalam membaca buku siswa maupun LAS hal ini memungkinkan kesiapan siswa dalam belajar dari rumah sudah cukup baik.

Selanjutnya pada kategori menulis memiliki rata-rata 30.9 merupakan proporsi waktu yang cukup baik bagi siswa dengan batas toleransi yang sudah ditetapkan yaitu $30 \% \leq$ PWI $\leq 40 \%$. Hal ini menunjukkan bahwa menulis merupakan hal yang biasa saja dalam menyelesaikan masalah, sehingga siswa cenderung mengemukakan ide mereka pada lembar kertas. Pada kategori berdiskusi, rerata yang diperoleh sebesar 27.9 merupakan proporsi waktu yang cukup baik bagi bagi siswa dengan batas toleransi yang sudah ditetapkan yaitu $25 \% \leq \mathrm{PWI} \leq 35 \%$. Hal tersebut menunjukkan bahwa siswa sudah mulai dapat menemukan makna berdiskusi dengan baik, dimana tidak ditemukan lagi beberapa siswa yang beranggapan bahwa siswa pintar menjadi ketua kelompok diskusi dan mengerjakan sendiri tanpa menayakan pendapat siswa yang lain. Demikian juga dengan kategori perilaku siswa yang tidak relevan, nilai rata-ratanya yaitu 4.3, merupakan proporsi waktu yang baik bagi siswa dengan batas toleransi yang sudah ditetapkan yaitu $0 \% \leq \mathrm{PWI}$ $\leq 5 \%$. Rerata pada kelompok pembelajaran konvensional lebih tinggi jika dibandingkan dengan kelompok pembelajaran kontekstual. Yang artinya bahwa selama kegiatan pembelajaran konvensional berlangsung masih terdapat siswa yang meminta izin keluar ruangan. Berikut ini Gambar 11 yang menyajikan persentase aktivitas siswa pada masing-masing kelompok pembelajaran.

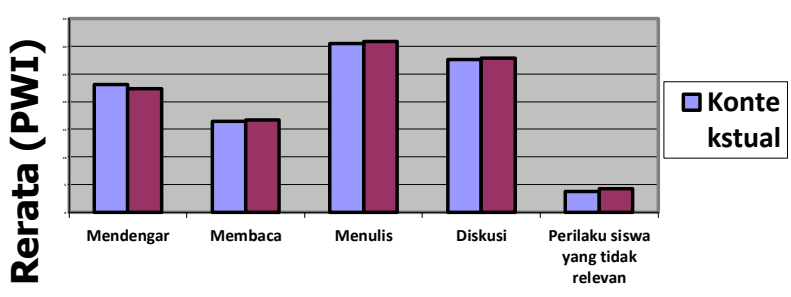

Aspek yang diamati

\section{Gambar 11. Persentase aktivitas siswa pada masing-masing pembelajaran}


Tabel 16. Analisis Kovarians untuk Rancangan Lengkap Kemampuan Berpikir Kreatif Siswa

Analisis Variansi untuk variabel X dan Y

\begin{tabular}{|c||c|}
\hline SSTO $_{y}$ & 9226,183 \\
\hline \hline SSTR $_{y}$ & 5742,817 \\
\hline \hline SSE $_{y}$ & 3483,367 \\
\hline \hline SSTOx & 389,6 \\
\hline \hline SSTRx & 21,6 \\
\hline \hline SSEx & 368 \\
\hline
\end{tabular}

Analisis Variansi Gabungan

\begin{tabular}{|c||c|}
\hline SSTOxy & 977,4 \\
\hline \hline SSTRxy & 352,2 \\
\hline \hline SSExy & 625,2 \\
\hline \hline SSTO(adj) & 6774,154 \\
\hline \hline SSE(adj) & 2421,206 \\
\hline \hline SSTR(adj) & 4352,947 \\
\hline \hline MSTR(adj) & 4352,947 \\
\hline MSE(adj) & 42,4773 \\
\hline$F^{*}$ & 102,477 \\
\hline \hline$F(0,95,1,58)$ & 4,006873 \\
\hline
\end{tabular}

Dari hasil perhitungan untuk kemampuan berpikir kreatif pada tabel 4.36 diperoleh $\mathrm{F}^{*}=$ $\frac{M S T R_{(a d j)}}{M S E_{(a d j)}}=\frac{4352,947}{42,4773}=102,477$ dan berdasarkan tabel $\mathrm{F}$, untuk $\alpha=5 \%$ diperoleh $\mathrm{F}_{(0,95,1,58)}=4,0068$. Berarti $\mathrm{F}^{*} \geq \mathrm{F}_{(0,95,1,58)}$ sehingga Ho : $\mathrm{r}_{1}=\mathrm{r}_{2}=0$ ditolak. Hal ini berarti ada perbedaan yang signifikan antara kemampuan berpikir kreatif siswa yang dikenai perlakuan pembelajaran konvensional dengan siswa yang dikenai perlakuan pembelajaran kontekstual

Tabel 17. Analisis Varians Untuk Uji Independensi Kemampuan Berpikir Kritis Matematika pada Kelas Pembelajaran Konvensional

\begin{tabular}{c||c||c||c||c||c||c|}
\hline SSR & SSTO & SSE & MSR & MSE & $F_{\text {hitung }}$ & $F_{\text {tabel }}$ \\
\hline \hline 535,309 & 1456,3 & 920,991 & 535,309 & 32,8925 & 16,2745 & 4,19597 \\
\hline
\end{tabular}

Dari hasil perhitungan pada table 17 untuk kemampuan berpikir kritis matematik diperoleh $\mathrm{F}$ $=16.2745$ dan berdasarkan tabel F, untuk $\alpha=5 \%$ diperoleh $\mathrm{F}_{(1-\alpha, 1: \mathrm{n}-2)}=\mathrm{F}_{(0.95,1,33)}=4,19$. Berarti

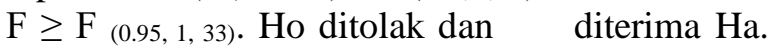
Artinya ada pengaruh positif (signifikansi) hasil uji awal kemampuan berpikir kritis matematik siswa (X) terhadap hasil uji akhir siswa (Y) untuk strategi pembelajaran konvensional.

Tabel 18. Analisis Varians untuk Uji Independensi Kemampuan Berpikir Kritis Matematika pada Pembelajaran Kontekstual

\begin{tabular}{c||c||c||c||c||c||c|}
\hline SSR & SSTO & SSE & MSR & MSE & $F_{\text {hitung }}$ & $F_{\text {tabel }}$ \\
\hline \hline 149,45 & 409,367 & 259,917 & 149,45 & 9,28274 & 16,0998 & 4,19597 \\
\hline
\end{tabular}

Dari hasil perhitungan pada Tabel 18 untuk kemampuan berpikir kritis matematik diperoleh $\mathrm{F}^{*}=16,0998$ dan berdasarkan Tabel F, untuk $\alpha=$ 5\% diperoleh: $\mathrm{F}_{(1-\alpha, 1: n-2)}=\mathrm{F}_{(0,95,1,33)}=4,19$. Berarti

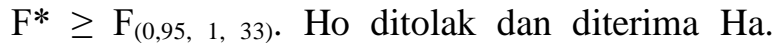
Artinya ada pengaruh positif (signifikansi) hasil uji awal kemampuan berpikir kritis matematik siswa (X) terhadap hasil uji akhir siswa (Y) untuk strategi pembelajaran kontekstual.

Tabel 19. Analisis Kovarians untuk Rancangan Lengkap Kemampuan Berpikir Kritis Siswa

Analisis Variansi untuk variabel X dan Y

\begin{tabular}{|c||c|}
\hline SSTO $_{y}$ & 1977,733 \\
\hline \hline SSTR $_{y}$ & 112,0667 \\
\hline \hline SSE $_{y}$ & 1865,667 \\
\hline \hline SSTOx & 467,9333 \\
\hline \hline SSTRx & 3,266667 \\
\hline \hline SSEx & 464,6667 \\
\hline
\end{tabular}

Analisis Variansi Gabungan

\begin{tabular}{|c||c|}
\hline SSTOxy & 531,4667 \\
\hline \hline SSTRxy & $-19,1333$ \\
\hline \hline SSExy & 550,6 \\
\hline \hline SSTO(adj) & 1374,107 \\
\hline \hline SSE(adj) & 1213,241 \\
\hline \hline SSTR(adj) & 160,8659 \\
\hline \hline
\end{tabular}




\begin{tabular}{|c||c|}
\hline \hline MSTR(adj) & 160,8659 \\
\hline MSE(adj) & 21,28493 \\
\hline$F^{*}$ & 7,557737 \\
\hline \hline$F(0,95,1,58)$ & 4,006873 \\
\hline
\end{tabular}

Dari hasil perhitungan untuk kemampuan berpikir kritis pada tabel 19 diperoleh $\mathrm{F}^{*}=$ $\frac{\operatorname{MSTR}_{(a d j)}}{M S E_{(a d j)}}=\frac{160,8659}{21,28493}=7,557737$ dan berdasarkan tabel $\mathrm{F}$, untuk $\alpha=5 \%$ diperoleh $\mathrm{F}_{(0,95,1,58)}=4,006873$. Berarti $\mathrm{F}^{*} \geq \mathrm{F}_{(0,95,1,58)}$ sehingga Ho : $r_{1}=r_{2}=0$ ditolak. Hal ini berarti terdapat perbedaan yang signifikan antara kemampuan berpikir kritis siswa yang dikenai perlakuan pembelajaran konvensional dengan siswa yang dikenai perlakuan pembelajaran kontekstual

\section{Pembahasan}

Pada bagian ini akan diuraikan deskripsi dan interprestasi data hasil penelitian. Deskripsi dan interprestasi dilakukan terhadap kemampuan berpikir kreatif siswa, kemampuan berpikir kritis siswa, aktivitas siswa, dan respon siswa terhadap masing-masing pembelajaran, dan pola jawaban siswa berdasarkan faktor-faktor yang dilibatkan dalam penelitian diantaranya adalah sebagai berikut :

\section{Faktor Pembelajaran}

Melihat hasil penelitian yang telah dikemukakan di atas, menunjukkan bahwa pembelajaran kontekstual secara signifikan lebih baik dalam meningkatkan kemampuan berpikir kreatif siswa jika dibandingkan dengan pembelajaran konvensional. Begitu juga dengan kemampuan berpikir kritis siswa bahwa pembelajaran kontekstual secara signifikan lebih baik dalam meningkatkan kemampuan berpikir kritis siswa jika dibandingkan dengan pembelajaran konvensional.

Jika kita perhatikan karakteristik kedua pembelajaran di atas, maka hal tersebut adalah sesuatu yang wajar hal itu disebabkan karena, secara teoritis pembelajaran kontekstual memiliki keunggulan dalam meningkatkan kemampuan berpikir kreatif dan berpikir kritis siswa. Sehingga, apabila keunggulan-keunggulan ini dimaksimalkan dalam pembelajaran di kelas sangat memungkinkan proses pembelajaran menjadi lebih baik. Keunggulan tersebut dapat dilihat melalui perbedaan pandangan terhadap karakteristik pembelajaran anatar lain :

\section{a. Bahan Ajar}

Bahan ajar yang dikembangkan dikemas dalam bentuk sajian masalah-masalah yang nyata (kehidupan sehari-hari). Bermula dari permasalahan yang nyata siswa diberikan kesempatan untuk belajar mengembangkan potensi melalui suatu aktivitas, memecahkan masalah dan menemukan solusi penyelesaian. Siswa didorong bertindak aktif mencari jawaban atas masalah, keadaan atau situasi yang dihadapi dan menarik kesimpulan melalui proses berpikir ilmiah yang kritis, logis dan sistematis.

Dalam pembelajaran konvensional, bahan ajar yang digunakan adalah sama dengan yang dipakai oleh guru dan kegiatan pembelajaran lebih banyak dilakukan dengan membahas contoh soal bersama kelompok ahli dan dilanjutkan dengan mempresentasikan hasil kerjanya sekaligus membenarkan hasil kerjanya yang telah di evaluasi oleh guru, serta mengerjakan kuis untuk memperoleh skor perkembangan. Hal inilah yang membuat kedua kelompok lebih baik dalam proses pembelajaran matematika.

\section{b. Guru}

Pada kelompok pembelajaran kontekstual ditegaskan bahwa guru sebagai fasilitator, berkeliling dari kelompok satu ke kelompok yang lain untuk mengamati dan memberi dorongan tentang berbagai kemungkinan proses penyelesaian soal yang baik dan benar. Berbeda dengan pembelajaran konvensional dimana guru menjelaskan kepada siswa dan memberikan contoh soal dalam menyelesaikan soal matematika.

Kendala yang dihadapi guru dalam menerapkan kedua pembelajaran adalah kecerdasan siswa di kelas relatif bervariasi, maka tingkat kesulitan yang dihadapi siswa dalam menyelesaikan soal pun beragam pula. Kesulitan guru dalam membelajarkan siswa dengan kecerdasan yang heterogen dapat diminimalkan dengan cara siswa bekerja sama dalam kelompok yang terdiri dari empat sampai lima orang. Mereka berinteraksi secara kooperatif untuk memecahkan masalah, yaitu saling berbagi gagasan/pendapat melalui tanya jawab dan coba-coba, Bentuk intervensi guru pada saat siswa bekerja sama dilakukan guru secara tidak langsung, yaitu dengan menggunakan teknik scaffolding dan pengajuan petunjuk. Dalam teknik scaffolding guru dituntut terampil menggunakan teknik bertanya, diantaranya yang sangat penting adalah 
memecah pertayaan kompleks bagi siswa menjadi pertayaan-pertayaan yang lebih sederhana yang terjangkau pikiran siswa pada saat itu. Pertayaan yang diajukan guru berupa pertanyaan terarah.

Perbedaan kedua kelompok pembelajaran tersebut terlihat pada proses pembentukan pengetahuan yang dilakukan guru dengan cara yang sangat berbeda. Pada pembelajaran kontekstual guru memberikan kesempatan kepada siswa untuk menyelesaikan masalah dengan menggunakan cara berpikir kreatif mereka sendiri sesuai dengan pengetahuan matematika yang telah mereka miliki. Sementara pada pembelajaran konvensional guru hanya menjelaskan kepada siswa bagaimana caranya mengerjakan soal pada contoh soal kemudian membimbing siswa pada saat siswa mengerjakan tugas mereka.

\section{c. Kemampuan Berpikir Kreatif}

Berdasarkan hasil tes kemampuan berpikir kreatif dari kelas kontrol dan kelas eksperimen dapat dilihat dari gabungan gambar berikut ini:

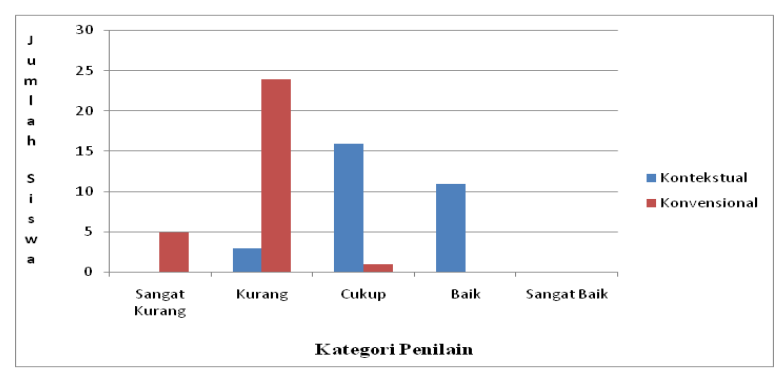

Gambar 12. Tes Kemampuan Berpikir Kreatif Siswa

Dari gambar di atas, dapat dilihat bahwa tingkat kemampuan berpikir kreatif pada kelas kontrol ada 5 orang yang termasuk pada kategori sangat kurang, untuk kategori kurang ada 24 orang, untuk kategori cukup ada 1 orang, untuk kategori baik tidak ada, dan untuk kategori sangat baik tidak ada. Sementara di kelas eksperimen untuk kategori sangat kurang tidak ada, untuk kategori kurang ada 3 orang, untuk kategori cukup ada 16 orang, untuk kategori baik ada 11 orang, dan untuk kategori sangat baik tidak ada. Terlihat bahwa terdapat perbedaan yang signifikan dan kecenderungan hasil yang lebih tinggi antara kemampuan berpikir kreatif di kelas kontrol dengan kemampuan berpikir di kelas eksperimen.

Hal ini dapat diakibatkan karena perbedaan tingkat kognitif dan metode yang digunakan oleh guru dalam melaksanakan kegiatan belajar mengajar. Hal ini sejalan dengan teori perkembangan Piaget yang menyakini bahwa perkembangan intelektual terjadi pada saat individu menghadapi tantangan dan pengalaman baru.

\section{d. Kemampuan Berpikir Kritis}

Berdasarkan hasil tes kemampuan berpikir kritis dari kelas kontrol dan kelas eksperimen dapat dilihat dari gabungan gambar berikut ini :

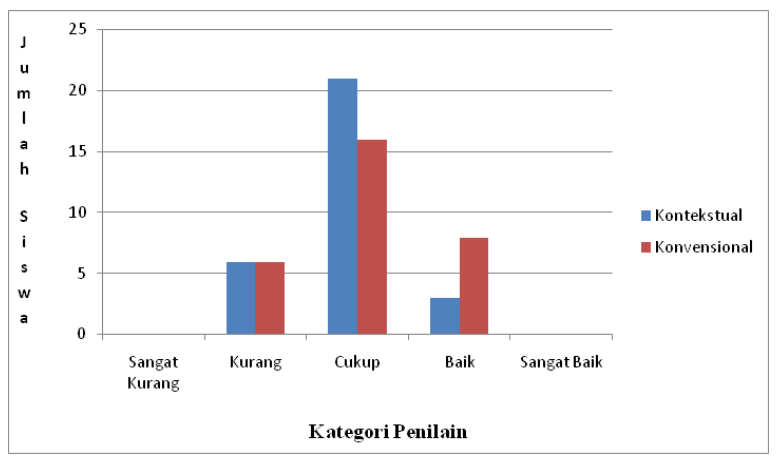

Gambar 13. Tes Kemampuan Berpikir Kritis Siswa

Dari gambar di atas, dapat dilihat bahwa tingkat kemampuan berpikir kritis pada kelas kontrol tidak ada orang yang masuk pada kategori sangat kurang, untuk kategori kurang ada 6 orang, untuk kategori cukup ada 16 orang, untuk kategori baik ada 8 orang, dan untuk kategori sangat baik tidak ada. Sementara di kelas eksperimen tidak ada orang yang masuk kategori sangat kurang, untuk kategori kurang ada 6 orang, untuk kategori cukup ada 21 orang, untuk kategori baik ada 3 orang, dan untuk kategori sangat baik tidak ada. Terlihat bahwa terdapat perbedaan yang signifikan dan kecenderungan hasil yang lebih tinggi antara kemampuan berpikir kritis di kelas kontrol dengan kemampuan berpikir kritis di kelas eksperimen.

Hal ini dapat diakibatkan karena perbedaan tingkat kognitif dan metode yang digunakan oleh guru dalam melaksanakan kegiatan belajar mengajar. Hal ini sejalan dengan teori perkembangan Piaget yang menyakini bahwa perkembangan intelektual terjadi pada saat individu menghadapi tantangan dan pengalaman baru.

\section{e. Peran Aktif Siswa}

Dari hasil analisis deskriptif data aktivitas aktif siswa dan berdasarkan kriteria yang ditetapkan diperoleh kesimpulan bahwa aktivitas aktif siswa dalam pembelajaran kontekstual adalah memenuhi batas toleransi waktu ideal. Hal ini dimungkinkan karena pembelajaran kontekstual memiliki beberapa karakteristik yaitu masalah dari soal-soal terbuka. 
Dilihat dari persentase aktivitas siswa berdiskusi antara sesama teman sebesar $27.6 \%$ dan aktivitas mencatat hal-hal yang relevan $16.45 \%$, persentase ini sudah efektif. Hal ini terjadi karena pembelajaran kontekstual membuat siswa saling berpikir bersama dan bekerja sama. Siswa yang memiliki kemampuan yang lemah ikut aktif berdiskusi dan bertanya dengan siswa yang memiliki kemampuan yang tinggi. Hal ini sesuai pendapat Vigotsky bahwa perlunya interaksi yang terus-menerus baik antara siswa satu dengan yang lain, maupun antara siswa dengan guru sehingga siswa mendapat manfaat positif dari interaksi tersebut.

Berkurangnya dominasi guru dalam menerangkan materi, membuat siswa memiliki banyak waktu untuk dapat menyelesaikan masalah dengan baik. Siswa berdiskusi dalam kelompoknya masing-masing untuk menemukan cara penyelesaian masalah. Hal ini didukung oleh data hasil penelitian tentang rata-rata persentase aktivitas siswa yang menggunakan waktu menemukan cara untuk menyelesaikan masalah sebesar $30.45 \%$.

Rara-rata persentase aktivitas siswa berdiskusi/bertanya antara siswa dengan temannya, dan antara siswa dengan guru yaitu 27.6\%. Walaupun aktivitas ini melebihi batas toleransi tetap hal ini menunjukkan bahwa kemampuan siswa yang menyampaikan ide dan berdiskusi dengan guru adalah sejalan. Aktivitas siswa selama pembelajaran kontekstual terlihat aktif dan kritis serta memiliki semangat yang tinggi dalam memecahkan masalah yang diberikan. Sementara untuk kategori penilaian portofolio dapat disimpulkan bahwa siswa menganggap sepele dengan tugas yang diberikan oleh guru sehingga rata-rata persentase portofolio memiliki nilai yanr terendah.

\section{f. Respon Siswa}

Dari hasil analisis deskriptif data aktivitas aktif siswa dan berdasarkan kriteria yang ditetapkan diperoleh kesimpulan bahwa respon siswa dalam pembelajaran kontekstual adalah positif. Jika dilihat dari rata - rata persentase respon siswa dari keseluruhan komponen pembelajaran yaitu terhadap materi pelajaran, buku siswa, lembar aktifitas siswa, suasana belajar, dan cara guru mengajar dalam pembelajaran konvensional sebesar 87,08\%; berdasarkan kriteria pencapaian efektifitas yang ditetapkan yaitu respon siswa dikatakan positif apabila rata - rata persentase keseluruhan komponen respon siswa terhadap pembelajaran konvensional lebih besar atau sama dengan $80 \%$, maka disimpulkan bahwa respon siswa terhadap pembelajaran konvensional adalah positif. Jika dibandingkan dengan rata-rata keseluruhan respon pada pembelajaran konvensional maka pembelajaran kontestual sedikit lebih baik dari pada pembelajaran konvensional

\section{Kesimpulan dan Saran \\ 1. Kesimpulan:}

Dari hasil penelitian dan analisa data yang sudah diuraikan, dapat diambil beberapa kesimpulan sebagai berikut :

1. Dari hasil perhitungan uji $\mathrm{F}$, dihasilkan bahwa $F_{\text {hitung }}=102,477$ dan $F_{\text {tabel }}=$ 4,006873 dengan taraf signifikan sebesar 5\% Jika $F_{\text {hitung }} \geq F_{\text {tabel }}$ maka $\mathrm{H}_{0}$ ditolak dan $\mathrm{H}_{\mathrm{a}}$ diterima artinya terdapat perbedaan yang signifikan antara kemampuan berpikir kreatif siswa yang memperoleh pembelajaran kontekstual dengan siswa yang memperoleh pembelajaran konvensional.

2. Dari hasil perhitungan uji $\mathrm{F}$, dihasilkan bahwa $F_{\text {hitung }}=7,557737$ dan $F_{\text {tabel }}=$ 4,006873 dengan taraf signifikan sebesar 5\% Jika $F_{\text {hitung }} \geq F_{\text {tabel }}$ maka $\mathrm{H}_{0}$ ditolak dan $\mathrm{H}_{\mathrm{a}}$ diterima artinya terdapat perbedaan yang signifikan antara kemampuan berpikir kritis siswa yang memperoleh pembelajaran kontekstual dengan siswa yang memperoleh pembelajaran konvensional

3. Keaktifan siswa dalam pembelajaran kontekstual dan konvensional memenuhi batas toleransi.

4. Rata - rata persentase keseluruhan komponen respon siswa terhadap pembelajaran kontekstual dan konvensional lebih besar atau sama dengan $80 \%$, maka disimpulkan bahwa respon siswa terhadap pembelajaran kontekstual dan konvensional adalah positif.

5. Proses penyelesaian jawaban siswa dengan menggunakan pembelajaran kontekstual memiliki kriteria baik. Hal ini ditunjukkan dengan jawaban siswa dalam menyelesaikan tes kemampuan berpikir kreatif dan berpikir kritis siswa lebih baik pada kelas pembelajaran kontekstual dibandingkan dengan pembelajaran konvensional. 


\section{Saran}

Berdasarkan hasil penelitian dan kesimpulan yang telah disajikan maka selanjutnya peneliti menyampaikan saran yang kiranya dapat memberikan manfaat kepada pihak-pihak yang terkait atas hasil penelitian ini, diantaranya:

a. Bagi Guru Matematika

* Pembelajaran kontekstual pada
menekankan kemampuan berpikir kreatif dan berpikir kritis siswa sangat baik sehingga dapat dijadikan sebagai salah satu alternatif untuk menerapkan pembelajaran matematika yang inovatif khususnya dalam mengajarkan materi Geometri Bidang Datar.

* Perangkat pembelajaran yang dihasilkan dapat dijadikan sebagai bandingan bagi guru dalam mengembangkan perangkat pembelajaran matematika dengan pembelajaran kontekstual pada pokok bahasan geometri bidang datar.

* Diharapkan guru matematika dapat menciptakan suasana pembelajaran yang menyenangkan, memberi kesempatan pada siswa untuk mengungkapkan gagasannya dalam bahasa dan cara mereka sendiri, berani beragumentasi sehingga siswa akan lebih percaya diri serta berpikir kreatif dan berpikir kritis dalam menyelesaikan masalah yang dihadapinya.

* Diharapkan guru perlu menambah wawasan tentang teori-teori pembelajaran dan model pembelajaran yang inovatif agar dapat melaksanakannya dalam pembelajaran matematika sehingga pembelajaran biasa secara sadar dapat ditinggalkan sebagai upaya dapat meningkatkan hasil belajar siswa.

b. Kepada Lembaga Terkait

* Perlu adanya sosialisasi dalam memperkenalkan pembelajaran kontekstual kepada guru dan siswa sehingga kemampuan yang dimiliki siswa khususnya kemampuan berpikir kreatif dan berpikir kritis siswa dapat meningkat.

* Diharapkan pembelajaran kontekstual dapat dijadikan sebagai salah satu alternatif dalam meningkatkan kemampuan siswa khususnya kemampuan berpikir kreatif dan berpikir kritis siswa pada pokok bahasan Geometri Bidang Datar sehingga dapat dijadikan masukan bagi sekolah untuk dikembangkan sebagai strategi pembelajaran yang efektif untuk mata pelajaran lain.

c. Kepada Peneliti Lanjutan

* Dapat dilakukan peneliti lanjutan dengan pembelajaran kontekstual dalam melihat perbedaan kemampuan berpikir kreatif dan berpikir kritis siswa untuk memperoleh hasil penelitian yang inovatif.

* Sebelum dilakukan penelitian, peneliti perlu bersosialisasi dalam memperkenalkan tentang pembelajaran kontekstual kepada guru dan siswa sehingga penelitian dapat dilakukan dengan baik.

* Rancanglah perangkat pembelajaran dengan efektif, sesuaikan indicator kemampuan dan alokasi waktu yang harus dicapai

\section{E. Daftar Pustaka}

Octavia Shilphy A. 2020. Model model Pembelajaran : Yogyakarta :CV Budi Utama

Saeful Anam. 2021 Group Investigation; Konsep dan Implementasi dalam Pembelajaran. Lamongan: Academia Publication

Arikunto, Suharsimi.2011. Dasar-Dasar Evaluasi Pendidikan. Jakarta : Bumi .Aksara.

Asra, Sumiati, 2013. Metode Pembelajaran. Bandung : Wacana Prima.

Hartono. 2012.Statistik Untuk Penelitian . Yogyakarta : Pustaka Pelajar.

Istarani, 2012. 58 Model Pembelajaran Inovatif. Medan : Media Persada

Komalasari, Kokom. 2013. Pembelajaran Kontekstual. Bandung : Refika Aditama.

Riduwan. 2013. Metode dan Teknik Menyusun Tesis. Bandung : Alfabeta.

Rusman. 2012. Model-Model Pembelajaran Jakarta :Grafindo Persada.

Sagala, S. 2003. Konsep Dan Makna Pembelajaran. Bandung : Alfabeta 